\title{
Revolution! Svenska erfarenheter från Ryssland.
}

Alexander Husebye (red.), med bidrag af: Bengt Jangfeldt, Ulrika Knutson, Martin Kragh, Benito Peix Geldart \& Gunnar Åselius

Näringslivshistoria 11

Karlskrona: Förlaget Näringslivshistoria 2018

124 sider, 37 illustrationer. ISBN 9789198426595

Omtalt af Birgitte Beck Pristed [Ph.d., lektor i Ruslandstudier ved Afdeling for Globale Studier, Aarhus Universitet, birgitte.pristed@cas.au.dk]

Mens Den Russiske Revolution indtager en selvfølgelig og fremtrædende plads i arbejderbevægelsens historie, har de skelsættende begivenheder i tiden omkring februar og oktober 1917 kun været genstand for mere spredt opmærksomhed inden for feltet af erhvervshistorie. Bolsjevikkernes afskaffelse af det etablerede, kapitalistiske økonomiske system, afvisningen af det internationale handels- og finansvæsen, nationaliseringen af industri og banker og konfiskeringen af privat ejendom synes umiddelbart at udgøre et slutpunkt, snarere end et udgangspunkt for det at skrive virksomhedshistorie. Erhvervshistoriske fagartikler i internationale tidsskrifter som Business History med emne- eller titelord som »sovjetisk» eller »russisk" kan tælles på én hånd. Så det er et prisværdigt svensk indspark til revolutionens internationale virksomhedshistorie, det erhvervshistoriske arkiv i Stockholm, Centrum för Näringslivshistoria, nu har leveret, først i form af et dagsseminar afholdt i anledning af 100året for revolutionsdagen 7. november 2017, efterfulgt af en trykt antologi Revolution! Svenska erfarenheter från Ryssland redigeret af centrets leder, Alexander Husebye, og med bidrag af slavist Bengt Jangfeldt, forfatter Ulrika Knutson, seniorforsker ved svensk udenrigspolitisk institut Martin Kragh, arkivar Benito Peix Geldart samt militærhistoriker Gunnar Åselius. Det rigt illustrerede katalog har et grafisk indbydende og letlæseligt format, også egnet til et bredere publikum, og kan med fordel læses i forlængelse af det tidligere bind i samme serie Swedish business history in Russia, 1850-1917 (2014), redigeret af Martin Kragh.

Bogen åbner med Knutsons korte, formidlende tekst om et stykke svensk "Leniniana», nemlig revolutionslederens jakkesæt, som han købte i Stockholm på sin gennemrejse fra Schweiz til Petrograd i foråret 1917. Udover det underholdende i at den i øvrigt asketiske Lenin altså her fremstilles på shopping som konsument i den svenske hovedstads detailhandel, fremstår anekdoten om jakkesættet dog mest 
som et kuriosum, mens en mere indgående og relevant beskrivelse af Lenins forbindelser til det socialistiske miljø i Stockholm savnes.

Kraghs bidrag giver en informativ og solid baggrund for Sveriges vigtige handelsmæssige stilling i Rusland i tiden op til revolutionen, hvor Sverige profiterede både på sin nære geografiske placering til Rusland og neutralitetspolitikken under 1 . Verdenskrig. Siden 1880'erne gennemløb Rusland en kraftig industrialiseringsproces, og som følge heraf ekspanderede store svenske foretagender stærkt på det russiske marked, herunder LM Ericsson, ASEA, Lux, SKF, AGA, Brødrene Nobels petroleumsselskab i Baku samt en række andre større og mindre virksomheder. Kragh anfører, at i krigsårene fra 1914 til 1917 øgedes svensk eksport af jern, stål og maskiner til Rusland fra 31,1 til 127,5 millioner kroner, og dermed udgjorde det russiske afsætningsmarked $9,5 \%$ af den samlede svenske eksport i revolutionsåret 1917. Bolsjevikkernes magtovertagelse fik derfor mærkbare konsekvenser for svensk økonomi: Ifølge Kraghs beregninger svarede de svenske tab på den postrevolutionære nationalisering og konfiskering af industrivirksomheder til hele 5,9\% af svensk BNP i 1917.

Noget af det fascinerende ved læsningen af antologien er, at den belyser, hvordan svenske diplomater og entreprenører i samspil vedblev at øjne nye muligheder for svensk-russiske eksporteventyr også efter revolutionen, blandt andet leverede NOHAB-værkstedet i Trollhättan i 1920 fem hundrede lokomotiver til bolsjevikkerne og modtog betaling i tsaristiske guldreserver. Selv om svensk Ruslandseksport igen gik frem fra 1920 til 1922 efter Borgerkrigens afslutning og indførelsen af Lenins Ny Økonomiske Politik, nåede den dog aldrig igen op på det før-revolutionære niveau.

Hvordan revolutionen ikke blot fik økonomiske, men også alvorlige menneskelige omkostninger for den betydelige gruppe af svenske expats, der var bosat i Rusland i 1917, giver Jangfeldts kapitel os indblik i. Af et svensktalende mindretal på oprindeligt ca. 6.000 indbyggere i det multietniske Russiske Imperiums hovedstad i 1917 var kun 140 tilbage i Petrograd i 1921. Jangfeldts hovedkilde, ingeniør John Tuneld, som opholdt sig i Sovjetunionen helt frem til 1936, hvis hidtil ikke-publicerede erindringer er optrykt i uddrag i artiklen, belyser den vanskelige situation for de tilbageblevne, men også en stærk selvforståelse af indbyrdes svensk solidaritet, der blandt andet kom til udtryk i Skandinavisk Velgørenhedsforening, som støttede fattige landsmænd, der havde mistet alt. Blandt dem, der ikke lod sig evakuere i løbet af 1918, var også den svenske Røde Kors repræsentation, som tilså krigsfanger i de sibirske lejre. Læst i forlængelse af Kraghs kapitel fremstår denne humanisme paradoksal: Først slår Sverige mønt på en omfangsrig eksport af stål, maskiner og materiel til den russiske forsvarsindustri, dernæst sender man "Sibiriens svenske engel" over for at sætte plaster på såret.

I Geldarts bidrag kommer Centrum for Näringslivshistorias omfattende samling af svenske virksomhedsarkiver for alvor til deres ret. Foruden et nyttigt forskningsoverblik over studier af svensk virksomhed i Rusland, præsenterer Geldart et 
udvalg af kildetekster i form af korrespondance fra svenske virksomhedsudsendinge i revolutionens Rusland til hovedsæderne hjemme i Sverige. Trods beretningerne om de tiltagende kaotiske tilstande, er det slående ved læsningen, i hvilken grad de svenske forretningsfolk formår at opretholde en upåvirket business as usual-attitude i deres afrapporteringer. Daglige udfordringer med likviditet og valutatransaktioner synes at fylde mere en storpolitik. I egen selvfremstilling forsøger direktør Hellström for Nordisk Kompagnis møbelfabrik i Moskva at fremstå mere pragmatisk end panisk, da han pænt må bede den ny revolutionære fabrikskomité lade deres bajonetter stå uden for døren, inden man kan sætte sig til forhandlingsbordet på kontoret.

Kataloget afsluttes med Åselius' kortfattede udblik på svensk sikkerhedspolitik i forhold til Rusland efter revolutionen. Han konkluderer, at mens Ruslands betydning som tilsyneladende umætteligt eksportmarked mindskedes for Sverige efter 1917, blev Sovjetunionen i stigende grad opfattet som en militær trussel. Derfor blev finsk selvstændighed revolutionens største geopolitiske gevinst for Sverige.

Helhedsindtrykket af antologien kunne være blevet bedre ved en mere håndfast redigering. Bidragene fremstår noget ujævnt og forskelligartede i kompleksitet, længde og implicit målgruppe, og man irriteres over gentagelser og overlap. Flere steder skæmmes teksten af faktuelle unøjagtigheder, og ved et enkelt bidrag er hele noteapparatet faldet ud. Dette ændrer dog ikke på, at antologien åbner for en særdeles interessant kildesamling med et svensk perspektiv på, hvordan man handler under en revolution, når alle gængse regler for både handel og handlen er ophævet. 